\title{
Pre-Sowing Seed Treatment Nanotechnology with Environment-Friendly Nanotube-Based Nanochips
}

\author{
Karpachev Vladimir V. ${ }^{1, a^{*}}$, Spiridonov Jury J. ${ }^{2, b}$, Voropaeva Nadezhda L. ${ }^{1, a}$, \\ Tkachev Alexey G. ${ }^{3, c}$, Shachnev Nikolai V. ${ }^{1, a}$, Figovsky Oleg L ${ }^{4, d}$ \\ ${ }^{1}$ Federal State-Financed Scientific Institute "All-Russian Rapeseed Research Institute" 398037, \\ Russia, Lipetsk, Boyevoy Proezd, 26 \\ ${ }^{2}$ Federal State-Financed Scientific Institute "All-Russian Scientific and Research Institute of \\ Phitopathology" \\ ${ }^{3}$ Tambov State Technical University, Tambov \\ ${ }^{4}$ Polymate Ltd.-INRC, Migdal Ha Emek, Israel \\ abionanotex_l@mail.ru, b spiridonov@vniif.ru, 'nanotam@yandex.ru, dfigovsky@gmail.com
}

Keywords: pre-sowing seed treatment, nanotechnology, nanotubes, nanochips, environmentfriendly, yields, field test

\begin{abstract}
This particular study deals with the impact of pre-sowing nanotube-based seed treatment technology on rapeseed (Brassica napus) growth and yield. During field tests we identified a significant yield increase as a result of applying the pre-sowing nanotube-based seed treatment technology. The main treatment agents were physiologically active nanochips consisting of carrier matrix nanotubes with eliciting activity ("Taunit", "Taunit-M", "Taunit-MD", and graphene). Enriching nanochips with insecticide-fungicide Kruizer-rape for guaranteed seed protection from crucifer flea allowed to raise the yield up to $8.08 \mathrm{t} / \mathrm{ha}-12.28 \mathrm{t} / \mathrm{ha}$.
\end{abstract}

\section{Introduction}

Carbon nanotubes have been proved to be widely applied in different areas of human activity as a nanoproduct with unique qualities [1]. The most significant features of nanotubes in terms of biology and medicine are high sorption capacity, low toxicity and ability to infiltrate cell membranes [2-9]. The test-studies (on tseriodafniyah, protococcal green algae, GMO culture of luminescent bacteria E.coli M-17 (test system (Ekolyum"), house mice) revealed that the carbon nanotubes refer to III-IY hazard class on ecotoxicological five-point scale. The tests have also indicated the ability of multi-walled carbon nanotubes to penetrate the roots and reach the leaves of plants as well, going up the conduction system and leaving cells undamaged (test object - sainfoin) [4-6]. Growth and seedling development stimulation along with an increased peroxidase activity were also confirmed (nanomaterial concentration - 100 to $1000 \mathrm{mg} / 1$ ). Nanotubes also accelerate roots, shoots and stems growth of chickpea (Cicer arietinum) at a concentration of carbon nanotube water-soluble fractions up to $6 \mathrm{~g} / \mathrm{l}$. Nanotubes promote the occurrence of "channels" in plants which enables plant cells to absorb water and nutrients more effectively [6] .

The test results of colloidal carbon tubes water solutions influence on rapeseed (soaking) indicated that all the studied concentrations of nanoparticles have a stimulating effect on root and stem length [8]. The root reaches its maximum length $(+70 \%$ to control level) at a nanomaterial concentration of $0.01 \%$; the stem reaches its maximum length $(+10 \%$ to control level $)$ at a nanomaterial concentration of $0.001 \%$. Significant differences were discovered between the effects of different nanomaterial concentration levels $(0.00001,0.0001$ and $0.01 \%)$ on root lenth. Although, soaking in nanomaterial solutions suppress the seeds germination and vigor (maximum $-50 \%$ to a control level at a concentration of $0.0001 \%$ ) [8].

Numerous test studies indicated that the exposure of tomato, tobacco, sainfoin, wheat, rapeseed seeds to nanotube-containing solutions led to stimulation of germination and plant growth; it also increased biomass accumulation and yields due to the penetration of nanotubes through seed 
shell. The studies have been performed in Arkansas University Little Rock Nanotechnology Center, Tambov State University (REC "Nanotechnologies and Nanomaterials") together with the Tambov State Technical University ("NanoTechCenter" Ltd.) [3-8].

The obtained data suggests that some of the nanotubes may have a positive effect on plants. Although, the results may vary, depending on the properties of nanomaterial, the plant and its cultivation conditions.

\section{Methodology}

Development and obtainment of new sorption - capacity (nano) chips for pre-sowing treatment, carbon-containing (nano) materials (carbon nanotubes, graphene, together with different plant protection means of biogenic nature (chitosan), pesticides (Cruiser-rape). Application norms were sharply reduced to model conditions in the case of infected backgrounds. The research is performed according to the Ruban et all. Patent № 12459518 USA (2012). [9-11].

The field test was conducted using the rape crop cultivation technology common for Central Chernozem region [12-13]. Environmentally friendly (nano) chips with elicitors (chitosan) introduced into their composition were used during the testing [14-16]. The crop was sprayed with biopesticides (chitosan) in the phases of 4-6 leaves and budding - flowering. In all the field tests phenological and phytosanitary surveillance and surveys were carried out according to the generally accepted methods and recommendations developed [13]. To protect rape crop from weeds and pests it was treated with herbicides and insecticides during the vegetation period (Zelek Super (0.5 1/ha), Salsa (20g/ha); insecticide spraying with Fastak (0.15 1/ha).

\section{Results}

This particular study deals with the impact of pre-sowing nanotube-based seed treatment technology on rapeseed (Brassica napus) growth and yield. Rapeseed treated and untreated (control level) with nanochips were grown in Petri dishes on filter paper for 10 days [17]. The nanochip components were chosen according to the published data and results of the previous studies. Determination of vigor and germination was carried out in accordance with [17]. The linear dimensions and weight of aboveground and underground parts of plants were observed in dynamics [16].

"Taunit"-series multi-walled carbon nanotubes (nanocarbon contents: 95-98 wt.\%) produced by "NanoTechCenter" Ltd. (Tambov, Russia) were used in the study [18]. These products represent quasi-one-dimensional, nanoscale, polycrystalline, filamentous graphite cylindrical formations with internal channels. Their characteristics are given in Table 1, and scanning electron micrographs of their surfaces are presented in Fig. 1.

Our lab research indicated sharp germination activation of rapeseed after pre-sowing nanotube-based seed treatment. The seed were treated by applying carbon nanotubes to the seed surface. "Taunit", "Taunit-M", "Taunit-MD and graphene (carbon monolayer enriched with physiologically active substances) were used as basic means of treatment. The number of germinating seeds among the treated ones on the first day was $20.2-32.5 \%(19.8 \%$ - untreated seeds); on the second day it went up to $90,5-93,0 \%$ with an obvious increase of germination, vigor, length of the seedlings and raw mass accumulation [9]. This may be due to penetration of physiologically active multifunctional nanochips inside the seeds and further to the cells and tissues of seedlings. 
Table 1. Principal characteristics of the "Taunit"-series multi-walled carbon nanotubes.

\begin{tabular}{|c|c|c|c|c|}
\hline \multirow{2}{*}{ Parameter } & \multicolumn{4}{|c|}{ MWCNTs } \\
\cline { 2 - 5 } & Taunit & Taunit-M & Taunit-MD & Taunit-4 \\
\hline External diameter, $\mathrm{nm}$ & $20-70$ & $8-15$ & $30-80$ & $4-8$ \\
\hline Internal diameter, $\mathrm{nm}$ & $5-10$ & $4-8$ & $10-20$ & $1-2$ \\
\hline Length, $\mu \mathrm{m}$ & $\geq 2$ & $\geq 2$ & $\geq 20$ & $\geq 100$ \\
\hline $\begin{array}{c}\text { Total amount of impurities, \%: intitial } \\
\text { (after purification) }\end{array}$ & $\leq 5$ & $\leq 5$ & $\leq 5$ & $\leq 5$ \\
\hline Bulk density, g cm ${ }^{-3}$ & $0.4-0.6$ & $0.03-0.05$ & $0.03-0.05$ & $0.03-0.05$ \\
\hline Specific surface area, $\mathrm{m}^{2} \mathrm{~g}^{-1}$ & $\geq 120-130$ & $\geq 300-320$ & $180-200$ & 650 \\
\hline Thermal stability in air, ${ }^{\circ} \mathrm{C}$ & $\leq 600$ & $\leq 600$ & $\leq 600$ & $\leq 600$ \\
\hline
\end{tabular}

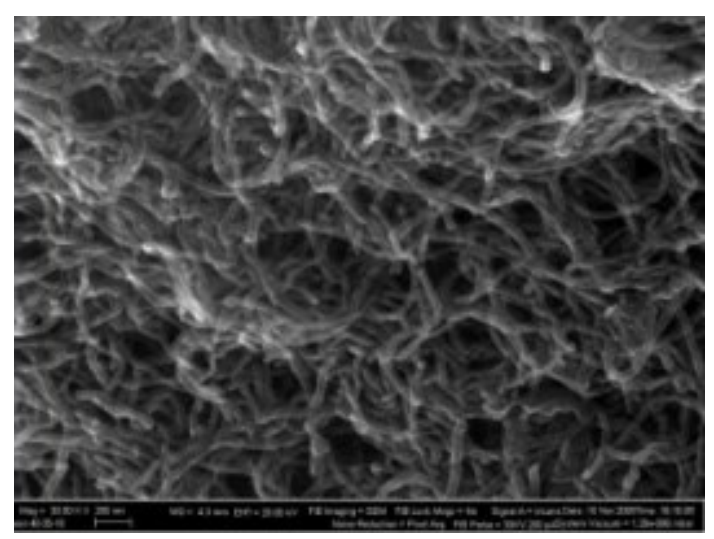

a

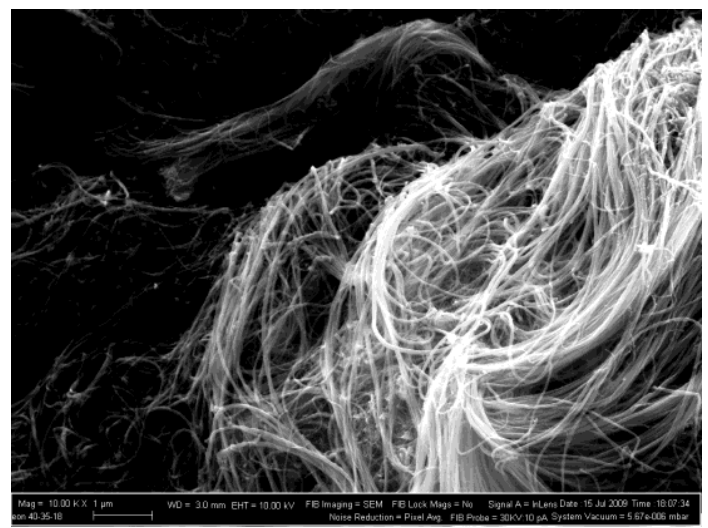

c

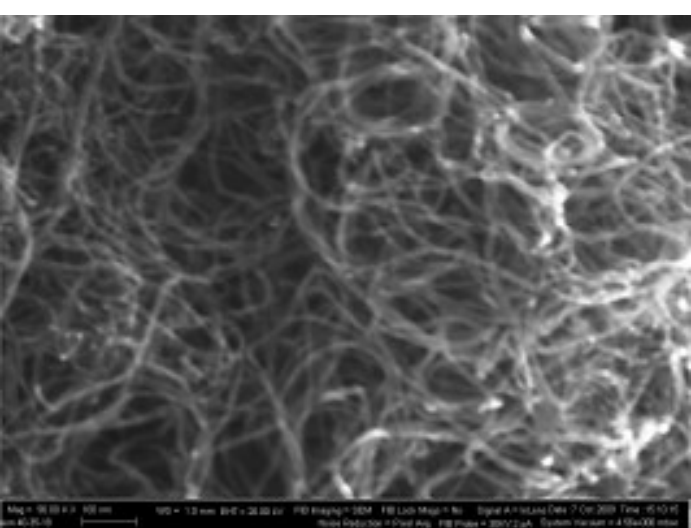

b

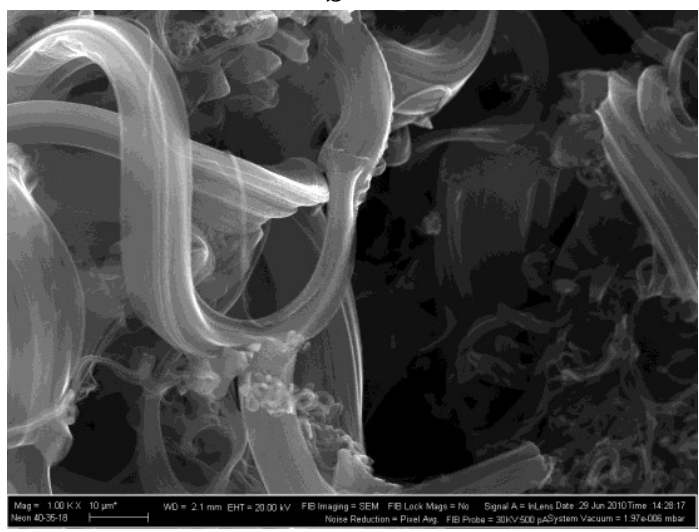

d

Figure 1. Scanning electron micrographs of the MWCNTs "Taunit" (a), "Taunit-M" (b), "TaunitMD" (c), and "Taunit-4" (d).

During the field tests we identified a significant yield increase as a result of applying the pre-sowing nanotube-based seed treatment technology. The main treatment agents were physiologically active nanochips consisting of carrier matrix nanotubes with eliciting activity ("Taunit", "Taunit-M", "Taunit-MD and graphene). Enriching nanochips with insecticide-fungicide Kruiser-rape for guaranteed seed protection from crucifer flea allowed to raise the yield up to $8.08 \mathrm{t}$ / ha - $12.28 \mathrm{t}$ / ha. (see Table 2).

The results of our studies suggest that carbon nanotubes create additional channels and ensure effective water supply in seedlings, which, in turn, accelerates the process of growth. There also can be more complex mechanisms for stimulation of seed germination process associated with altered biochemical status and the expression of certain genes [6, 8]. 
Table 2. Field test results.

\begin{tabular}{|c|c|c|c|c|c|c|c|c|c|}
\hline \multirow{2}{*}{ Conditions } & \multicolumn{3}{|c|}{$\begin{array}{l}\text { Yield increase to control } \\
\text { level, c/ha }\end{array}$} & \multicolumn{3}{|c|}{$\begin{array}{l}\text { Average yield, } \\
\text { c/ha }\end{array}$} & \multicolumn{2}{|c|}{$\begin{array}{l}\text { Content in } \\
\text { rapeseed, \% }\end{array}$} & \multirow{2}{*}{$\begin{array}{l}1000 \\
\text { seed } \\
\text { weight } \\
\text { Gr (av) }\end{array}$} \\
\hline & 2014 & 2015 & Av & 2014 & 2015 & Av & $\begin{array}{l}\text { Pro- } \\
\text { tein }\end{array}$ & fat & \\
\hline $\begin{array}{lr}\text { Common technology: } \\
\text { pre-sowing } & \text { seed } \\
\text { treatment } & \text { with } \\
\text { Cruiser }(10 & 1 / \mathrm{t}) \text {; } \\
\text { herbicide } & \text { crops } \\
\text { spraying with } & \text { Zelek } \\
\text { Super }(0.51 / \text { ha }), \text { Salsa } \\
(20 \mathrm{~g} / \mathrm{ha}) \text { insecticide } \\
\text { spraying with } & \text { Fastak } \\
(0.15 \mathrm{l} / \mathrm{ha}) & \end{array}$ & +4.0 & +5.3 & +4.58 & 18.9 & 23.8 & 21.35 & 23.6 & 43.4 & 3.33 \\
\hline $\begin{array}{l}\text { Sowing } \\
\text { treatment }- \text { without } \\
\text { level }\end{array}$ & -- & --- & -- & 14.9 & 18.5 & 16.77 & 23.7 & 43.5 & 3.40 \\
\hline \multicolumn{10}{|l|}{$\begin{array}{l}\text { Sowing seeds treated } \\
\text { with nanochips based } \\
\text { on }\end{array}$} \\
\hline 1-taunit & +3.1 & +3.3 & +3.22 & 18.0 & 21.8 & 19.99 & 23.7 & 43.4 & 3.42 \\
\hline $\begin{array}{l}\text { 2-taunit and Cruiser } \\
\text { (half doze) }\end{array}$ & +5.9 & +10.4 & +8.08 & 20.8 & 28.9 & 24.85 & 23.8 & 42.8 & 3.48 \\
\hline \multicolumn{10}{|l|}{$\begin{array}{l}\text { Sowing seeds treated } \\
\text { with nanochips based } \\
\text { on }\end{array}$} \\
\hline 1-taunit M & +3.0 & +4.2 & +3.56 & 17.9 & 22.7 & 20.33 & 23.6 & 43.6 & 3.50 \\
\hline $\begin{array}{l}\text { 2-taunit } M \text { and } \\
\text { Cruiser (half doze) }\end{array}$ & +9.3 & +11.0 & +10.8 & 24.2 & 29.5 & 26.85 & 23.7 & 43.2 & 3.56 \\
\hline \multicolumn{10}{|l|}{$\begin{array}{l}\text { Sowing seeds treated } \\
\text { with nanochips based } \\
\text { on }\end{array}$} \\
\hline 1-taunit MD & +4.0 & +4.9 & +4.38 & 18.9 & 23.4 & 21.15 & 23.7 & 43.7 & 3.49 \\
\hline $\begin{array}{l}\text { 2-taunit MD and } \\
\text { Cruiser (half doze) }\end{array}$ & +8.4 & +11.6 & +9.93 & 23.3 & 30.1 & 26.70 & 23.8 & 43.5 & 3.47 \\
\hline \multicolumn{10}{|l|}{$\begin{array}{l}\text { Sowing seeds treated } \\
\text { with nanochips based } \\
\text { on }\end{array}$} \\
\hline 1-grathen & +4.9 & +5.5 & +5.13 & 19.8 & 24.0 & 21.90 & 23.6 & 44.6 & 3.49 \\
\hline $\begin{array}{l}\text { 2-grathen and Cruiser } \\
\text { (half doze) }\end{array}$ & +10.9 & +13.8 & +12.28 & 25.8 & 32.3 & 29.05 & 23.8 & 44.4 & 3.50 \\
\hline $\mathrm{Hcp}_{05}, \mathrm{c} / \mathrm{ha}$ & & & & & $1.51 / 1 .($ & & 0.33 & 0.71 & 0.33 \\
\hline
\end{tabular}




\section{Summary}

Treating seeds with the use of nanotechnology leads to forming nanodimentional structures on the seed surface. These structures make mineral nutrition more efficient, provide a better protection and development for plants, and increase productivity. Considering the above, nanoporous materials can be effectively used as a means of transfer for various types of plant protection and nutrition, accelerating germination and plant growth. Use of nanomaterials decreases rates of chemical plant protection products applied as a part of nanochip. The developed technology perfectly fits the concept of introducing green agricultural products to the market and countering biosphere ecocide. More than 4 million of xenobiotics have been recently introduced to the mankind due to the growth of industrial production and intensive use of fossil fuels and chemicals. Negative impact of chemical pressure on biosphere (which is now recognized by the majority of scholars as a living being) has dramatically increased, especially in developed countries. The use of biopesticides as part of eco-friendly nanochip for pre-sowing seed treatment allows to meet the world's increasing demand for ecogically safe and clean agricultural products.

\section{Acknowledgements}

The work was performed as a part of R\&D task within the Federal Target Program N 06342014-0016, "Develop an environmentally safe (nano) technology of pre-sowingseed treatment of brassica crops using (nano) chip-based biopesticides", end within the Federal Target Program "Research and Development in Priority Areas of the Scientific and Technological Complex of Russia for 2014-2020" (State Contract No. 14.577.21.0091 of July 22, 2014; Unique Identifier for Applied Scientific Research: RFMEFI57714X0091).

\section{References}

[1] A.Y. Godymchuk, P.N. Savelev, F.P. Zykova, Ecology of nanomaterials, Moscow, Russia, 2012.

[2] V.A. Zakharenko, Nanofitosanitation - scientific field that combines nanotechnology and advanced protection of plants. Part 3. Biosecurity (nano) materials and nanotechnology in nanofitosanitarii, Agrochemistry. 5 (2011) 3-8.

[3] E.A. Smirnova et al., Carbon nanotubes penetrate the tissues and cells, and have a stimulating effect on the sainfoinseedlings Onobrychisarenaria (Kit.), Acta Naturae. 3(1) (2011) 106-113.

[4] E.A. Smirnova et al., Uptake and accumulation of multiwalled carbon nanotubes change the morphometric and biochemical characteristics of Onobrychisarenaria seedlings, Frontiers of Chemical Science and Engineering. 6(2) (2012) 132-138.

[5] S. Tripathi, S.K. Sonkar, S. Sarkar, Growth stimulation of gram (Cicer arietinum) plant by water soluble carbon nanotubes, Nanoscale. 3(3) (2011) 1176-1181.

[6] Information on http://www.agroxxi.ru/arhiv-novostei/nanotehnologi-perspektiva-i-dljaselskogo-hozjaistva.html.

[7] Information on www.abercade.ru/research/industrynews/2678.html.

[8] A.A. Gusev et al., Morphometric Parameters and Biochemical Status of Oilseed Rape Exposed to Fine-Dispersed Metallurgical Sludge, PHMB-Stabilized Silver Nanoparticles and Multi-Wall Carbon Nanotubes, Advanced Materials Research. 880 (2014) 212-218.

[9] E. Pshenichnikova et al., Environmentally friendly (nano) chips based on nanotubes for agriculture, in: Proceedings of the International scientific-practical conference "Methods and techniques in plant breeding and plant growing", School of young scientists on ecological and genetic bases of the northern crop in the International scientific-practical conference, Kirov, Russia, 2015, pp. 184-186.

[10] I.N. Ruban et.al. Biologically active multifunctional nanochips and method application thereof for production of high-quality seed. USA Patent, 12459518 (2012).

[11] V.V. Karpachev, Cruiser-rape, Lipetsk, Russia, 2010. 
[12] V.V. Karpachev, Rapeseed - the crops of the 21st century, Lipetsk, Russia, 2010.

[13] V. Karpachev et al., The long-term resource-spring rapeseed production technology: guidelines, Moscow, Russia, 2008.

[14] Yin Heng, Zhao Xiaoming, Du Yuguang, Oligochitosan: a plant diseases vaccine - a review, Carbohydrate Polymers. 82(1) (2010) 1-8.

[15] E.I. Mohamed Badawy, I.Entsar Rabea, A biopolymer chitosan and its derivatives as promising antimicrobial agents against plant pathogens and their applications in crop protection, International Journal of Carbohydrate Chemistry. (2011) 29-64.

[16] N. Voropaeva et al., Innovative application technology for challenging inducers of disease resistance in spring rape in (nano) chips, International Letters of Chemistry, Physics and Astronomy. 42 (2015) 36-44.

[17] GOST 12038-84, Seeds of agricultural crops. Germination determination approaches, 2011.

[18] Yu.I. Golovin, R.A. Stolyarov, A.G. Tkachev, The process for obtaining bulk nanostructured material, RF Patent 2475445, (2013). 